\title{
Editor's Column
}

As far as we know, Robert Owen's experiments within business in improving the conditions of the worker and, indeed, in improving the worker, himself, probably left no permanent effect on the thinking of British businessmen. It is significant today, when the responsibilities of business in our complex industrial society are being widely recognized, to note the reactions of a sensitive businessman to the early manifestations of the social problems brought by the Industrial Revolution. Mr. Peter Gorb, the author of the article entitled "Robert Owen as a Businessman," entered the employment of a manufacturing concern in Wales after receiving the M.B.A. degree from the Harvard Graduate School of Business Administration in June, 1951. His specialty is employee relations.

Professor Leonard J. Arrington, in his article dealing with the Iron Manufacturing Company of Utah, points to an experience in economic planning, and its implementation which took place over a period beginning some 70 years before planning of this kind became a favorite subject with scholars, bureaucrats, and some businessmen in the United States. Although this example does not lead to any positive conclusions concerning the efficacy of the business planning and activities carried on, jointly, by officers and members of the Church of Jesus Christ of Latter-day Saints, it does point to an interesting and rewarding subject for investigation. The development of adminis trative capacity and the mobilization of capital which this process involved were certainly different from the experience in other pioneer communities and may have been important in the growth of business among the Mormons.

The article entitled "Shoemaking in the Post-Revolutionary Period: The Business Records of Three Cordwainers of Reading, Massachusetts," is a small segment of a study in process of the history of the worker in the shoe industry in Massachusetts. Its author, Mr. John Philip Hall, has discovered valuable materials hitherto unused by historians, particularly records of labor organizations.

In his article on the "Development of Railway Officialdom," the 
third installment of "The Early Business History of Four Massachusetts Railroads," Professor Kennedy deals with the very beginnings of the development of railroad operating organization. From such beginnings, railroads led in the development of large administrative organizations in this country.

Two lines on the monument at the grave of the founder of the American condensed milk industry summarize the man's life, according to a new book, Gail Borden, Dairyman to a Nation:

\section{Tried and Failed.}

I Tried Again and Again, and Succeeded.

In this volume, Professor Joe B. Frantz, who teaches Business History at the University of Texas, presents a very readable personal biography of Borden. A man of a restless and inventive turn of mind, Gail Borden, aided by a New York financier and the Civil War, founded an important industry and a business out of which grew the concern today bearing his name.

Gerald T. White is the recipient of the Business History Fellowship for the academic year 1951-1952. This Fellowship, awarded by the Business Historical Society, carries a stipend of $\$ 3,000$ and enables an advanced scholar, usually the holder of a doctor's degree in history, to spend a year of study and research at the Harvard Graduate School of Business Administration. The recipient of the Fellowship is permitted free use of his time while at Harvard to pursue whatever aspects of the history of business he may choose. Dr. White will take a year's leave of absence from his duties as Associate Professor of History at San Francisco State College. 